\title{
Comparative Global Citizenship Education: A Critical Literature Analysis
}

\author{
Yuqing $\mathrm{HOU}$ \\ Graduate School of Education and Information Studies, University of \\ California, Los Angeles, CA, USA \\ yuqinghou@ucla.edu
}

\begin{abstract}
Over the past two decades, a wide range of research literature emerged in the field of Comparative and International Education (CIE) engaging in comparing Global Citizenship Education between nations. However, there is scant analysis that explores the research trends and findings in those comparative inquiries focusing on the theorizing and implementation of GCE in different national contexts. Through a systematic review of 12 research papers drawing from major CIE journals and relevant databases, the current inquiry will assist the international community of CIE in understanding the contribution and limitation of this important body of research, and its implications for future comparative studies on GCE. The analysis shows that the comparison reference in the existing literature on comparative GCE tends to be curriculum documents and frameworks while underrating the experiences and perceptions of individuals involved in the teaching and learning process. Moreover, the national settings where the comparative inquiries of GCE were conducted are highly limited in scope, mostly the developed countries in West Europe, East Asia, or North America. This trend limits the possibility to decolonize and transform CIE scholarship, which could be reversed with inclusion of new and diverse perspectives and knowledge in future GCE research.
\end{abstract}

\section{Keywords}

comparative studies - global citizenship education - literature review - globalization critical analysis 
In the face of an increasingly globalized and unpredictable world, the relevant role of education in helping learners grasp global issues and respond to global challenges is emphasized (UNESCO, 2015). As an educational response to the increasing international connectedness and deep concerns of global challenges, Global Citizenship Education (GCE) was prompted to help learners build a sense of belonging to a broader community with essential knowledge, attitudes, and behaviors developed at a global dimension (UNESCO, 2015). Specifically, GCE refers to an educational framework that aims to develop learners' awareness of the local, national, and global interconnectedness, sense of belonging to a broader community, and engagement in actions to resolve challenges the world is facing today (UNESCO, 2015). Although the idea of building citizenship in a global term has become prevalent in policies, practices, as well as research, the discursive and contested nature of GCE framework rendered its conceptualization and practice dissimilar in different national contexts. In view of the important role that the national education system plays in responding to global changes, a wide range of research papers appears in the last two decades engaging in comparing education for global citizenship in contrasting national contexts. However, there is scant analysis that explores the research trends and findings in those comparative inquiries focusing on the conceptualization and implementation of GCE in different national settings. To fill this lacuna, this article conducts a critical literature analysis focusing on the academic empirical studies that compare GCE between two or more nations published since 2000 , when GCE-related research began to flourish in Comparative and International Education (CIE) scholarship. Through searching literature database and relevant education journals, the author identified 12 research papers published between 2004 to 2020 featuring a comparison on how GCE is framed and practiced differently or alike across contrasting national settings, among which several important trends, dilemmas, and discussions emerged when a systematic review is applied. After outlining the theoretical framework of postcolonial theory and critical GCE, this article first discusses the literature on the nationstate as a core and useful unit in comparative studies of education, divergent approaches to G CE, and a nation's interpretation and adoption of GCE discourses. The methodology section elucidates the criteria and process for searching relevant research articles, followed by a short note of limitation implied in the inquiry. A discussion on overall findings and salient themes identified in the research process will be illustrated next, and the article will conclude with implications for future research in comparative GCE. 
The current analysis shows that the comparison reference in the existing literature on comparative G CE tends to be national curriculum frameworks, textbooks, and university programming documents while underrating the experiences and perceptions of individuals involved in the teaching and learning process. Moreover, the national settings where the comparative inquiries of GCE were conducted are highly limited in scope, mostly the developed countries in West Europe, East Asia, or North America. This trend limits the possibility of decolonizing and transforming CIE scholarship, which could be reversed with an inclusion of new and diverse perspectives and knowledge.

\section{Theoretical Framework}

Focusing on power and inequality implicit in a Eurocentric approach to education research, the postcolonial theory illuminates the rise of research on comparing GCE across different national settings. As Tikly and Bond (2013) assert, postcolonial research ethics in CIE allow researchers to interrogate the engrained "basis of Western rule" and a range of hegemonic forces that continuously shape and re-shape the basis of education in a postcolonial world. Postcolonial thought guides the author to carefully ponder over the power relations between the Global North and the Global South when the complex process of globalization overwhelmingly affects the postcolonial world. For the current analysis, it decenters Eurocentrism in analyzing different types of comparative inquiries of GCE and recognizes the importance of building a more inclusive understanding of citizenship development at both national and global levels.

Critical GCE provides another useful theoretical frame to guide the analysis. The discursive and contested nature of GCE framework runs the risk of reinforcing inequalities and turning GCE into another colonial project in education (Andreotti, 2010; Pashby \& Andreotti, 2015). The critical mode of GCE, according to Andreotti (2006), contrasts with a soft approach in that it deconstructs normative structures and calls for critical engagement in addressing social inequities. It also highlights a postcolonial view of GCE that encourages historical reflections and critical perspectives for students "to unlearn, to listen, to learn with others, and to reach out ready to work in solidarity with others" (Pashby \& Andreotti, 2015, p. 10). Seeing global citizenship as a commitment to the collective good, Torres (2017) argues that GCE should be "framed within a social justice education framework" (p. 17) and entail the development of 
'conscientization' or critical consciousness by Paulo Freire, which is in accordance with the mission of GCE (Torres \& Bosio, 2020).

\section{Literature Review}

\subsection{Nations as a Comparison Unit in Comparative Education}

As stated by Bray and Mason (2014), geographic entities traditionally act as a major focus of CIE analysis, and they encompass a variety of levels ranging from macro (i.e., world regions) to micro (i.e., classrooms). Comparison categories like policies, curriculum, or pedagogy in the field of education are inextricably tied to one or more specific places, and therefore exploring an education matter across different locations is deemed essential and relevant (Bray \& Mason, 2014). Among the wide-ranging geographic units in comparative education research, nation-state became a core and useful unit because the sector of education in many countries is centralized at the national level and education documents as well as other materials will be most available on a nation basis. In contrast to studies of individual countries, comparative studies in principle conduct a simultaneous comparison of more than one country (Bereday, 1964), which is the searching criteria for literature to be analyzed in the article. Large-scale comparisons involving a great number of countries around the world are also included in the analysis, as long as education for global citizenship is a major focus of comparison. The purpose of comparing an educational issue in different places varies. However, whether it employs an interpretive approach to fully grasp the issue or a causal-analytic method to examine to what extent the causation and outcome of education are different or alike in contrasting places, the underlying contextual features are at the center of analysis and deserve full attention from CIE researchers (Bray \& Mason, 2014).

\subsection{Global Citizenship Education and its Contrasting Approaches}

As the desired outcome of GCE, global citizenship is arguably contested in nature, considering both 'global' and 'citizenship' are open to debate with regard to their meanings and implications. The component of education within GCE, according to Hatley (2019), "blurs this (global citizenship) further and is often left unexamined" (p. 89), which raises another important question about what globally oriented citizenship is and how to teach it. When mapping out the discursive terrain of GCE, Pashby et al. (2O2O) identified neoliberal, liberal, and critical as three prominent typology orientations for GCE-related frameworks. Based on economic rationale and competition-oriented approach, neoliberal types of GCE stress education's role in accumulating human capital 
to gain personal advantage and national prosperity (Andreotti, 2006; Stein, 2015). Education within this neoliberal orientation tends to be instrumental, market-driven, and standardized (Gaudelli, 2009; Camicia \& Franklin, 2011), which has been often questioned in research. Liberal oriented GCE, by contrast, draws on cultural or moral insights and is more likely to advocate cultural diversity (Andreotti, 2006), democracy, and universal values such as human rights (Oxley \& Morris, 2013) with less response to West-centrism and global inequality. Critical GCE finds the status quo oppressive and aims to address social injustice and challenge the Eurocentric perspectives on modernization, international relations, and global citizenship.

\subsection{Nation-States and Global Citizenship Education}

In response to the challenges brought by globalization and international exchange, nation-states became a crucial policymaker and actor in the field of global education, and research also finds it encourages the inclusion of global citizenship related content in the curriculum (Goren \& Yemini, 2017). It is crucial to point out that GCE is a contingent notion (Andreotti, 2010), the meaning and implementation of which can only be fully understood and explained in a specific geographic context, and in this case, the nation-states. Considering that those in power have great authority in formulating and implementing GCE policies, Hatley (2019), Swanson and Pashby (2016) contend that GCE tends to be co-opted and endorsed by national government and institutions to further their own agendas and political interests. Therefore, the nation-state is a stakeholder of GCE and will develop a particular type of global citizenship aligning with their interests and desired values. Literature suggests neoliberal informed GCE is the dominant form found within the most nation-level GCE discourses. Irrespective of social justice concerns, neoliberal GCE emphasizes competitive workforce development (Cho \& Mosselson, 2018; Hamdon \& Jorgenson, 2011) and university's internationalization goals, which systematically reproduces inequality and marginalization. Another nation-centric view on GCE prioritizes national security and foreign policies. For example, Frey and Whitehead (2009) state that the expansion of international education in the United States is mainly for local concerns, especially pertaining to the issues around national security and economic interests rather than global aspirations, and this trend for prioritizing local needs will impede the research agendas and especially the transformative potentials of GCE (Parmenter, 2011). The recent rise of xenophobic nationalism (Pashby et al., 2020) and populist nationalism (Dorio, 2018) further complicates the relationship between nation and globe and makes the analysis of studies comparing GCE between nations necessary and timely. 
Since the goal is to explore the trends, development, and major discussions of comparative studies of GCE, the author turns to electronic databases and education journals to search literature that compares GCE in at least two contrasting national contexts. Large-scale research that involves a great number of countries is also included. This analysis does not intend to make an exhaustive list of all relevant literature, so the search has mainly focused on empirical, peer-reviewed publications after 2000 when research on GCE is flourishing in CIE scholarship. Keywords used in the search include 'global citizenship', 'education', and 'comparison' (searched in combination) and their similar descriptors like 'globalization', 'cosmopolitan citizenship', 'comparing countries', etc. and these key terms are searched in the most commonly used databases in the field of education such as JSTOR, ERIC, and EBSCOhost. Literature is also searched in several CIE journals such as Comparative Education Review, Compare: A Journal of Comparative and International Education, and Research in Comparative and International Education to increase the number of results. One inclusion criterion is that GCE needs to be the key comparison theme of the research, considering that global citizenship might be a trivial topic for studies focusing on other aspects of citizenship.

Sometimes comparatists focus on a sub-national geographical or administrative area as a point of comparison, for example, comparing the province of Alberta in Canada and Scotland, as a country and part of the United Kingdom (see, e.g., Swanson \& Pashby, 2016) or comparing Singapore and Hong Kong, as a Special Administrative Region of China, (see, e.g., Alviar-Martin \& Baildon, 2016). Although these comparative studies are not in keeping with general nation-level comparison, it could be argued that a province or state is heavily influenced by national policies, and thus it is reflective of the ideologies and values a national government has in terms of citizenship education. Therefore, a sub-national comparison of GCE is also included in the analysis. All literature that meets the above criteria is then grouped based on their comparison reference, and a summary table that lists all reviewed literature is provided in Table 1. In terms of limitation, the analysis does not take studies written in non-English language into account, so it cannot give a full picture of comparative studies of GCE. In addition, it does not capture the regional and local variations in promoting citizenship beyond the national borders. 
TABLE $1 \quad$ Reviewed articles

\begin{tabular}{|c|c|c|}
\hline $\begin{array}{l}\text { Comparison } \\
\text { reference }\end{array}$ & $\begin{array}{l}\text { National settings } \\
\text { of comparison }\end{array}$ & Publication title \\
\hline \multirow{6}{*}{$\begin{array}{l}\text { national } \\
\text { curriculum } \\
\text { frameworks }\end{array}$} & $\begin{array}{l}\text { Hong Kong and } \\
\text { Taiwan }\end{array}$ & $\begin{array}{l}\text { "Globalization and Citizenship Education in Hong } \\
\text { Kong and Taiwan" (Wing-Wah Law, 2004) }\end{array}$ \\
\hline & $\begin{array}{l}\text { Japan and New } \\
\text { Zealand }\end{array}$ & $\begin{array}{l}\text { "Global Citizenship, Cultural Change, and } \\
\text { Education Policy in Japan and New Zealand" } \\
\text { (Parmenter, 2010) }\end{array}$ \\
\hline & $\begin{array}{l}\text { Scotland and } \\
\text { Alberta }\end{array}$ & $\begin{array}{l}\text { "Towards a Critical Global Citizenship? A Com- } \\
\text { parative Analysis of GC Education Discourses in } \\
\text { Scotland and Alberta" (Swanson \& Pashby, 2016) }\end{array}$ \\
\hline & $\begin{array}{l}\text { Hong Kong and } \\
\text { Singapore }\end{array}$ & $\begin{array}{l}\text { "Context and Curriculum in Two Global Cities: A } \\
\text { Study of Discourses of Citizenship in Hong Kong } \\
\text { and Singapore" (Alviar-Martin \& Baildon, 2016) }\end{array}$ \\
\hline & $\begin{array}{l}\text { Scotland and } \\
\text { South Korea }\end{array}$ & $\begin{array}{l}\text { "Global citizenship, migration and national cur- } \\
\text { riculum: A tale of two nations" (Patterson \& Choi, } \\
2 \mathrm{O} 8 \text { ) }\end{array}$ \\
\hline & $\begin{array}{l}\text { Singapore and } \\
\text { Hong Kong }\end{array}$ & $\begin{array}{l}\text { "Taming cosmopolitanism: the limits of national } \\
\text { and neoliberal civic education in two global cit- } \\
\text { ies" (Baildon \& Alviar-Martin, 2O2O) }\end{array}$ \\
\hline \multirow[t]{2}{*}{ textbook } & $\begin{array}{l}\text { Over } 6 \text { o coun- } \\
\text { tries around the } \\
\text { world }\end{array}$ & $\begin{array}{l}\text { "Cosmopolitanism in Civic Education: Exploring } \\
\text { Cross-National Trends, 1970-2008" (Bromley, } \\
\text { 2009) }\end{array}$ \\
\hline & & $\begin{array}{l}\text { "Portraying the Global: Cross-national Trends in } \\
\text { Textbooks' Portrayal of Globalization and Global } \\
\text { Citizenship" (Buckner \& Russell, 2013) } \\
\text { "Fostering Global Citizens? Trends in Global } \\
\text { Awareness, Agency, and Competence in Text- } \\
\text { books Worldwide, 1950-2011" (Lee, 2020) }\end{array}$ \\
\hline \multirow[t]{2}{*}{$\begin{array}{l}\text { university } \\
\text { programming } \\
\text { documents }\end{array}$} & $\begin{array}{l}\text { Ireland and } \\
\text { Canada }\end{array}$ & $\begin{array}{l}\text { "Ethical Globalization or Privileged Interna- } \\
\text { tionalization? Exploring Global Citizenship } \\
\text { and Internationalization in Irish and Canadian } \\
\text { Universities" (Khoo, 2011) }\end{array}$ \\
\hline & Japan and UK & $\begin{array}{l}\text { "Global citizens or global workers? Comparing } \\
\text { university programmes for global citizenship } \\
\text { education in Japan and the UK" (Hammond \& } \\
\text { Keating, 2018) }\end{array}$ \\
\hline $\begin{array}{l}\text { student } \\
\text { perceptions }\end{array}$ & US and Australia & $\begin{array}{l}\text { "Global Citizenship and Study Abroad- A Compar- } \\
\text { ative Study of American and Australian Under- } \\
\text { graduates" (Dolby, 2008) }\end{array}$ \\
\hline
\end{tabular}


Twelve comparative studies of GCE are finally included in the analyzing process, and the analysis shows that the comparison references in the existing literature on comparative GCE tend to be national curriculum frameworks, textbooks, and university programming documents. A full table of reviewed studies is presented as Table 1 , and all studies were grouped by their comparison reference. Studies with the same comparison reference were listed following a chronological order by publication dates. Overall, six studies use national curriculum frameworks for comparison, while the rest studies focus on comparing textbooks, university programming documents, and student perceptions, respectively. The search also identified a few recent GCE studies making comparisons on teacher education between countries (see, e.g., Bamber et al., 2016; Tarozzi, \& Mallon, 2019), which is an emerging area of GCE research that looks into how frameworks of GCE would inform and be incorporated into teacher education programs. However, considering that this type of research often examines the involvement of multiple stakeholders such as higher education institutions, NGOs (non-government organizations), teacher educators, government authority, etc. and deals with broad aspects from professional standards to structural support (Bamber et al., 2016), such comparative studies are beyond the scope of the current analysis focusing on single comparison reference. In the same vein, UNESCO-initiated reports concerned with comparative analysis of GCE (see, e.g., Cox, 2017) found in the search are not considered either, given UNESCo's unique organizational goal for education monitoring and assessment. These two strands of GCE research are worthy of future study.

A vast majority of comparative studies of GCE in existing literature focuses on the national curriculum or policy documents of different countries as the key reference of comparison to explore their commonalities or differences for their incorporation of GCE, while fewer research efforts were made to compare textbooks, university programming documents, or student perceptions. In terms of methodology, while textbook comparisons use a quantitive approach and are concerned with a cross-national trend in the adoption of GCE, the rest literature is more likely to compare only two countries through qualitative methods like document analysis. A significant finding derived from the analysis is that the national settings where the comparative inquiries of GCE were conducted are highly limited in scope, mostly the developed countries or sub-national areas located in West Europe, East Asia, or North America. Amidst all countries selected for comparison, 
Japan, Canada, Hong Kong (officially as a Special Administrative Region of China), UK (especially its nation of Scotland) appear multiple times and GCE related materials in these places tend to be compared with the counterparts in countries also characterized with privileges and advanced economic development. Under this situation, a few studies turn to the same curriculum documents for analysis. For example, both Swanson and Pashby (2016) and Patterson and Choi (2018) use Curriculum for Excellence (CfE) to explore Scotland's national discourses of GCE, although the other country of comparison is different. The following section will look into each reference of comparison to better understand the research trends and major findings in comparative studies of GCE.

\subsection{Compare National Curriculum Frameworks}

A bulk of studies on comparative GCE use national curriculum frameworks to examine the commonalities and differences in the adoption of global citizenship related content for different countries. As an easily accessible reference for comparison, curriculum frameworks reflect a society's official discourses of citizenship and attitudes that policymakers have toward globalization, diversity, and other social changes. Given that nearly all the six studies focusing on national curriculum comparison employ (critical) discourse analysis or a similar method such as content/textual analysis, a pattern of convergence in terms of research methodology is discerned. Using national curriculum as a focus of comparison, these studies seek to explore how educational frameworks between nations would deal with the tensions between the national and global since they all recognize the vital role that education plays in responding to the economic, demographic, and socio-cultural changes that globalization brought to the society.

Analyzing the notions of cosmopolitanism, cultural diversity, and migration in-depth, these studies strive to understand to what extent and in what ways the idea of global citizenship is discussed in relation to the national relationships within the national curriculum framework. One consistent finding across all six studies is that national/local citizenship is still at the center in the national curriculum of comparison, although the discourse of global citizenship and the importance of respecting differences is discussed frequently in framing what is aspired in a global age. In addition, these studies argue that tensions and ambiguities would increase when promoting a global form of citizenship in a curriculum that prioritizes nation-centric agendas, especially in terms of identity formation and civic engagement (Parmenter, 2010). The concerns about preserving national identities and traditions against increasing 
diversity and uncertainty in societies make the discourse of global citizenship elusive and difficult to grasp, primarily in the compared cases of Asian societies such as Japan, South Korea, and Singapore. Another commonality found across the six studies is that the compared national curriculum tends to associate global citizenship with the emphasis on skills and knowledge for learners to engage in the global economy. This leads to a conclusion that the framing of global citizenship in the curriculum of comparison is instrumental and neoliberal-oriented, which lacks critical components to challenge inequality since it expects learners only to adapt to a global environment and accept changes (Swanson \& Pashby, 2016).

\subsection{Compare Textbooks}

Employing primarily quantitative research methods, three studies use secondary-school textbooks as a reference for comparison for G CE. Specifically, they conduct a large-scale cross-national analysis on the extent to which the notion of global citizenship and globalization were incorporated in civics, social studies, and history textbooks over the years since 1970. All derived from the same large, longitudinal project founded at Stanford University aiming to map out the content changes in social science textbooks around the world, these three publications reveal an overall increase for years in textbook content to include the topic of global citizenship (or its main aspects such as global awareness, etc.) and of globalization across more than 6o countries. Despite difficulties in knowing the frequency of use and real impact on learners (Bromley, 2009), textbooks serve as a useful and practical reference of comparison since they can reveal a nation's civic ideals and expectations for future generations.

In addition to showing an increasing trend to include global citizenship related content in textbooks, the three studies disclose the regional variations and national-level characteristics in predicting the content change in textbooks. For example, both Buckner and Russell (2013) and Lee (2020) suggest that a country's membership in ING Os (international non-government organizations) predicts a greater likelihood for its textbooks to have global citizenship content. Lee (2020) further implies that democratic countries are more likely to integrate aspects of global citizenship in textbooks than non-democratic regimes. Moreover, some regional variance is observed, and Buckner and Russell (2013) find the textbooks in Latin American countries have a higher chance to include global citizenship content than those in Western nations when a particular statistic model is operated. However, such a result is not consistent and warrants future investigations. 


\subsection{Compare University Programming Documents and Student Perceptions}

The frequent appearance of GCE programs and initiatives within the realm of higher education brings two studies to focus on the university's documents and policies in which GCE is the main theme. Concretely, they compare how higher education institutions in different national contexts incorporate global citizenship related concepts into their educational programs. Considering that the higher education sector worldwide is increasingly exposed to globalization and market forces, these studies are particularly concerned with how programming documents discuss the visions of and rationale for promoting global citizenship and implications it has for future higher education. Overall, those studies observe that the education for global citizenship as an important institutional agenda is inextricably linked to universities' broader internationalization efforts, the focus of which is often on international student recruitment, study abroad, internationalizing curriculum, international volunteering programs, etc. (Khoo, 2011). When exploring GCE programming at universities in Japan and the UK, the study by Hammond and Keating (2018) found programs in both countries highlight the interconnections between people and the needs to address global challenges. More importantly, they converge in their emphasis on learners' practical skills and employability, which cares more about the production of 'global workers' than global citizens. However, their institutional goal differs when considering Japan's program is to promote national identity and government agendas through GCE and the program in the UK is more concerned about enhancing university branding to compete in global higher education. Dolby's (2008) article is the only one among the reviewed papers that especially draws attention to student perceptions, and it compares how college students from the US and Australia develop a global identity as global citizens through study abroad. It finds US students tend to prioritize their national identity and have less affiliation to a broader community, while Australian students have a stronger identification as global citizens.

\section{Discussion}

A growing body of literature emerged over the past two decades in CIE scholarship to compare education for global citizenship in different national settings. Although CIE and GCE research both encompass more than nationstate comparisons and globalization disrupts the national basis of comparative education (Dale, 2005), the current analysis choose to focus on 
nation-level comparison because GCE is a contingent and country-specific notion (Andreotti, 2010; Phillips \& Schweisfurth, 2014) and government as a dominant GCE policymaker and actor (Hamdon \& Jorgenson, 2011) can mediate and have strong leverage in policy formation and implementation. The current analysis shows that the comparison reference in the existing literature on comparing GCE tends to be national curriculum frameworks, textbooks, and university programming documents. These works converge in their observations that the concept of global citizenship is increasingly incorporated in secondary- and college-level education for countries of comparison. However, they also find the idea of global citizenship is adopted to strengthen national and institutional agendas to maximize learners' competitiveness for a global economy, which is well noted as the sector of education is prone to neoliberal shifts in policies, governance, and regulations. Moreover, the national settings where the comparative inquiries of GCE were conducted are highly limited in scope, mostly the developed countries in West Europe, East Asia, or North America. With advanced economic development, the societies for comparison form an enclosed group of places that seem to be selected to showcase the 'best' practice for GCE and act as a reference point to reveal the status quo of citizenship development for a global dimension. This trend, however, must be questioned and counteracted by including more voices and perspectives from the Global South, especially what Misiaszek termed the "hard space" (2019). Facing "unique challenges to conducting GCE work," those hard spaces are either "heavily surveilled and regulated" or suffering from political instability (2019, p. 2). The view of hard space resonates with Torres (2017)'s wonderings on the central dilemmas of GCE, for both its theoretical and practical development, that is, "can we try to build a global citizenship education when so many nation-states have failed even to build national citizenship education, or when national citizenship building is still an abysmal work in progress?" (2017, p. x) Bearing this key conundrum in mind, the hard space deserves more room and presence in future GCE research, and global citizenship will never be a goal and action plan for only a couple of countries. Moreover, the reference of comparison should be expanded when exploring the development of global citizenship in different educational settings, and this observation suggests involving more human subjects such as learners and educators in comparative research and analysis of their experiences, perceptions, as well as actions in relation to global citizenship will enrich the GCE discourses with a bottom-up approach. Building access to students and teachers in different places also requires a more solid and reliable partnership between researchers and educational stakeholders, which is an important next step for the research community. 
When the basis of education is challenged and redefined by local and global forces, education for global citizenship will help us rebuild solidarity and deconstruct unequal power relations. Reviewing and critically analyzing the different types of inquiries on comparing GCE between nations, this paper strives to delineate this important research area by identifying major comparison themes, dilemmas, and findings across a number of research papers published between 2004 to 2020 . Comparative studies in the future should not only attend to the emergence and development of GCE in societies which are the privileged and active players in a globalized world, but also take notice of how (global) citizenship is governed and held back in one place or another, with an emphasis on examining how people perceive their educational spaces and experiences within it. For citizenship education educators and researchers, it is also important "to unlearn, to listen, to learn with others, and to reach out ready to work in solidarity with others" (Pashby \& Andreotti, 2015, p. 10) together with learners to make the world more connected and inclusive.

\section{References}

Alviar-Martin, T., \& Baildon, M. (2016). Context and curriculum in two global cities: A study of discourses of citizenship in Hong Kong and Singapore. Education Policy Analysis Archives, 24(58).

Andreotti, V. (2006). Soft versus critical global citizenship education. Policy and Practice: A Development Education Review, 3(Autumn), 40-51.

Andreotti, V. (2010). Postcolonial and post-critical global citizenship education. In Education and social change: Connecting local and globalperspectives (pp. 238-250).

Baildon, M., \& Alviar-Martin, T. (2020). Taming cosmopolitanism: the limits of national and neoliberal civic education in two global cities. Asia Pacific Journal of Education, 40(1), 98-111.

Bamber, P., Bullivant, A., Glover, A., King, B., \& McCann, G. (2016). A comparative review of policy and practice for education for sustainable development/education for global citizenship (ESD/GC) in teacher education across the four nations of the UK. Management in Education, 30(3), 112-120.

Bereday, G. Z. (1964). Comparative method in education. New York: Holt, Rinehart \& Winston.

Bray, M., Adamson, B., \& Mason, M. (Eds.). (2014). Comparative education research: Approaches and methods. Hong Kong University Press. 
Bromley, P. (2009). Cosmopolitanism in Civic Education: Exploring Cross-National Trends, 1970-2008. Current Issues in Comparative Education, 12(1), 33-44.

Buckner, E., \& Russell, S. G. (2013). Portraying the global: Cross-national trends in textbooks' portrayal of globalization and global citizenship. International Studies Quarterly, 57(4), 738-750.

Camicia, S. P., \& Franklin, B. M. (2011). What type of global community and citizenship? Tangled discourses of neoliberalism and critical democracy in curriculum and its reform. Globalisation, Societies and Education, 9(3-4), 311-322.

Cho, H. S., \& Mosselson, J. (2018). Neoliberal practices amidst social justice orientations: global citizenship education in South Korea. Compare: A Journal of Comparative and International Education, 48(6), 861-878.

Cox, C. (2018). Global citizenship concepts in curriculum guidelines of 10 countries: Comparative analysis.

Dale, R. (2005). Globalisation, knowledge economy and comparative education. Comparative education, $41(2)$, 117-149.

Dolby, N. (2008). Global citizenship and study abroad: A comparative study of American and Australian undergraduates. Frontiers: The Interdisciplinary Journal of Study Abroad, 17(1), 51-67.

Dorio, J. N. (2018). Lessons from Los Angeles: Self-study on teaching university global citizenship education to challenge authoritarian education, neoliberal globalization and nationalist populism. Journal of Global Citizenship \& Equity Education, 6(1).

Frey, C. J., \& Whitehead, D. M. (2009). International education policies and the boundaries of global citizenship in the US. Journal of Curriculum Studies, 41(2), 269-29o.

Gaudelli, W. (2009). Heuristics of global citizenship discourses towards curriculum enhancement. Journal of Curriculum Theorizing, 25(1), 68-85.

Goren, H., \& Yemini, M. (2017). Global citizenship education redefined - A systematic review of empirical studies on global citizenship education. InternationalJournal of Educational Research, 82, 170-183.

Hamdon, E., \& Jorgenson, S. (2011). Policy implications for global citizenship education in higher education in an age of neo-liberalism. Global citizenship education in postsecondary institutions: Theories, practices, and policies (pp. 260-272).

Hammond, C. D., \& Keating, A. (2018). Global citizens or global workers? Comparing university programmes for global citizenship education in Japan and the UK. Compare: A Journal of Comparative and International Education, 48(6), 915-934.

Hatley, J. (2019). Universal Values as a Barrier to the Effectiveness of Global Citizenship Education: A Multimodal Critical Discourse Analysis. International Journal of Development Education and Global Learning, 11(1), 87-102. 
Khoo, S. M. (2011). Ethical globalisation or privileged internationalisation? Exploring global citizenship and internationalisation in Irish and Canadian universities. Globalisation, Societies and Education, 9(3-4), 337-353.

Law, W. W. (2004). Globalization and citizenship education in Hong Kong and Taiwan. Comparative Education Review, 48(3), 253-273.

Lee, S. S. (2020). Fostering" Global Citizens"? Trends in Global Awareness, Agency, and Competence in Textbooks Worldwide, 1950-2011. Prospects: Quarterly Review of Comparative Education, 48, 215-236.

Misiaszek, L. I. (2019). An Introduction Label: Blending New Colors-Enriching the Canvases of Global Citizenship Education. In Exploring the Complexities in Global Citizenship Education (pp. 1-15). Routledge.

Oxley, L., \& Morris, P. (2013). Global citizenship: A typology for distinguishing its multiple conceptions. British Journal of Educational Studies, 61(3), 301-325.

Parmenter, L. (2010). Global citizenship, cultural change, and education policy in Japan and New Zealand. In Cultural change and persistence (pp. 183-201). New York: Palgrave Macmillan.

Parmenter, L. (2011). Power and place in the discourse of global citizenship education. Globalisation, societies and education, 9(3-4), 367-380.

Pashby, K., da Costa, M., Stein, S., \& Andreotti, V. (2020). A meta-review of typologies of global citizenship education. Comparative Education, 56(2), 144-164.

Pashby, K., \& Andreotti, V. (2015). Critical global citizenship in theory and practice. Research in global citizenship education (pp. 9-33).

Patterson, T., \& Choi, Y. (2018). Global citizenship, migration and national curriculum: A tale of two nations. British Journal of Educational Studies, 66(4), 477-496.

Phillips, D., \& Schweisfurth, M. (2014). Comparative and international education: An introduction to theory, method, and practice. A\&C Black.

Stein, S. (2015). Mapping global citizenship. Journal of College and Character, 16(4), 242-252.

Swanson, D. M., \& Pashby, K. (2016). Towards a critical global citizenship?: a comparative analysis of GC education discourses in Scotland and Alberta. Journal of Research in Curriculum Instruction, 20(3), 184-195.

Tarozzi, M., \& Mallon, B. (2019). Educating teachers towards global citizenship: A comparative study in four European countries. London Review of Education, 17(2), 112-125.

Tikly, L., \& Bond, T. (2013). Towards a postcolonial research ethics in comparative and international education. Compare: A Journal of Comparative and International Education, 43(4), 422-442.

Torres, C. A. (2017). Theoretical and empirical foundations of critical global citizenship education (Vol. 1). Taylor \& Francis. 
Torres, C. A., \& Bosio, E. (2020). Global citizenship education at the crossroads: Globalization, global commons, common good, and critical consciousness. PROSPECTS, 48(3-4), 99-113.

Unesco, (2015). Global Citizenship Education: Topics and Learning Objectives. Paris: UNESCO. 